\title{
PENGARUH KEPEMIMPINAN TRANSAKSIONAL TERHADAP KINERJA KARYAWAN PADA PT AL BAROKAH NATAR LAMPUNG SELATAN
}

\author{
Dita Evlin Ananda ${ }^{(1)}$, Husna Purnama ${ }^{(2)}$, Khairul Saleh ${ }^{(3)}$ \\ Fakultas Ekonomi Universitas Sang Bumi Ruwa Jurai \\ evlin_ditaananda@gmail.com, husna.purnama@fe.saburai.ac.id, khairul.saleh@fe.saburai.ac.id
}

\begin{abstract}
Abstrak. PT Al-Barokah Natar Lampung Selatan merupakan perusahaan yang bergerak dibidang pendistributoran gula pasir baik gula pasir dalam bentuk curah maupun kemasan. Permasalahan yang dihadapi oleh perusahaan adalah pengarahan serta pengawasan yang kurang kepada karyawan, sehingga karyawan kurang optimal untuk mengerjakan pekerjaan yang semestinya secara tanggung jawab dan loyalitas yang penuh. Divisi gula pada PT Al-Barokah sedikit kurang memperhatikan tanggung jawab pekerjaannya terhadap target penjualan. Hal tersebut dapat dilihat dari ketidak sesuaian imbalan dan adanya absensi karyawan hal ini berpengaruh terhadap target penjualan gula yang hasilnya kurang terrealiasi dengan baik. Untuk mengetahui berapa besar pengaruh kepemimpinan transaksional terhadap kinerja karyawan pada PT Al-Barokah Natar Lampung Selatan. Populasi dalam penelitian ini adalah seluruh karyawan PT Al Barokah Natar yang berjumlah 30 orang karyawan, dengan pelaksanaan tugasnya yaitu pada posisi seluruhnya baik supervisior maupun karyawan. Metode pengumpulan data menggunakan kuesioner dengan skala likert. Analisis data yang digunakan adalah analisis regresi sederhana. Hasil penelitian menunjukkan bahwa hipotesis penelitian mendukung yang menyatakan bahwa kepemimpinan transaksional berpengaruh positif terhadap kinerja karyawan. Pengaruh sebesar 67,60\% dan sisanya dipengaruhi oleh faktor lain yang tidak ada dalam penelitian. Saran pada perusahaan dalam penelitian ini adalah agar pihak perusahaan dapat memberikan sanksi apabila terjadi kesalahan dalam proses kerja yang dilakukan karyawan dan juga mempersiapkan rencana apa yang akan dilakukan agar optimal dalam menjalankan pekerjaan yang ada.
\end{abstract}

Kata kunci : Manajemen,,Karyawan, Dan Kinerja

\section{PENDAHULUAN}

Perkembangan dunia usaha yang semakin global menimbulkan persaingan yang sangat ketat diantara perusahaanperusahaan yang ada guna mendapatkan pangsa pasar yang dibidiknya. Perusahaanperusahaan yang saat ini ada dan siap berkompetisi serta bersaing dalam dunia usaha yang begitu kuat harus memiliki tingkat kualitas kinerja yang baik. Serta dalam rangka meningkatkan pencapaian dan sebagai upaya menciptakan manajemen yang efektif, hal ini memerlukan peran utama yang sangat penting yaitu karyawan yang trampil, kreatif, dan berkompeten dibidangnya.
Karyawan sendiri menjadi hal utama sebagai sumber daya manusia yang handal dan karyawan sangat berpengaruh bagi perusahaan. Sumber daya manusia sendiri memiliki peran utama dalam setiap kegiatan baik perusahaan maupun organisasi, dimana hal itu memberi gambaran bahwa manajemen sumber daya manusia merupakan faktor penting dan kunci utamanya ialah harus diperhatikan segala kebutuhannya.

Faktor yang menunjang perusahaan menjadi maju dan membuat karyawan nyaman di dalam perusahaan tersebut ialah karena adanya seorang pemimpin yang berpotensi dalam menjalankan fungsi kepemimpinannya agar para karyawan yang 
bekerja di perusahaan, dapat memberikan kinerja terbaiknya sesuai arahan dari pemimpinnya. Oleh sebab itu perusahaan memerlukan pemimpin yang mampu menjadi motivator maupun penggerak perubahan dalam perusahaannya sendiri maupun dalam sebuah organisasi.

Kepemimpinan transaksional yaitu dimana pemimpin menentukan apa yang harus dikerjakan oleh karyawan agar mereka dapat mencapai tujuan mereka sendiri atau organisasi dan membantu karyawan agar memperoleh kepercayaan dalam mengerjakan tugas tersebut (Bass,2006). Pemimpin transaksional pada hakikatnya menekan bahwa seorang pemimpin itu perlu menentukan apa yang harus dilakukan para bawahannya agar mencapai tujuan yang diinginkan. Kepemimpinan transaksional berpengaruh terhadap motivasi kerja bawahannya yang ditujukan untuk memperoleh imbalan kerja dalam jumlah yang layak dan sesuai dengan kinerja yang diberikan, sehingga dengan hal tersebut dapat memacu karyawan untuk bekerja lebih giat dan lebih baik.

Kepemimpinan secara transaksioal yang diberikan para atasan kepada karyawannya dapat mempengaruhi kinerja karyawan di dalam suatu perusahaan. Kinerja itu sendiri ialah merupakan sistem atau cara kerja yang menghasilkan suatu hasil yang baik.

Pada PT Al-Barokah Natar Lampung Selatan merupakan perusahaan yang bergerak dibidang pendistributoran gula pasir baik gula pasir dalam bentuk curah maupun kemasan. Pada tanggal 2 juli 2010 berlokasi di Natar Lampung Selatan dilakukan awal kerjasama yang dibangun dari PT induknya yaitu Sugar Grub Company yang bergerak dibidang produksi gula pasir. Kemudian diserahkanah agar dapat berdirinya distributor gula, guna membantu penstabilan penjualan di masyarakat agar tidak dimonopoli. PT AlBarokah membuat perjanjian pada beberapa
PT yang khususnya bergerak dibidang produksi gula pasir. PT tersebut ialah Gunung Madu Plantions (GMP), Sugar Grub (Indolampung), Bumi Waras (Bw). Tanggal 21 Juli 2010 PT Al-Barokah mulai berjalan memulai sebagai distributor.

PT Al-Barokah lebih cenderung terhadap terciptanya kepemimpinan transaksional, melalui hasil kegiatan seharihari yang di lihat peneliti. Kepemimpinan di PT Al-Barokah terlihat sudah cukup baik. Tetapi masih kurang dilihat dari indikator imbalan yang kurang seimbang dan masih adanya karyawan yang absen kerja serta ditambah kurangnya sedikit perhatian atasan yang berupa motivasi sehingga kinerja yang dilakukan sudah optimal tetapi masih harus perlu pertinjauan yang cukup. Imbalan mempunyai cakupan yang lebih luas daripada upah atau gaji. Imbalan mencakup semua pengeluaran yang dikeluarkan oleh perusahaan untuk pekerja, baik secara langsung, rutin atau tidak langsung (Ruky, 2006).

Masih adanya karyawan dalam waktu kerja yang bolos ataupun tidak masuk kerja tanpa keteranngan yang jelas hal ini bertanda karyawan belum sepenuhnya nyaman untuk menyampaikan permasalahannya. Dalam hal ini juga karyawan ditunjang dari segi imbalan belum merasakan keadilan, mungkin hal inilah yang menjadi beberapa faktor masalah yang ada di dalam perusahaan.

Masih ada bawahan yang tidak mendapat imbalan yang sesuai dengan apa yang telah dikerjakannya atau dengan kata lain imbalan tidak merata yang dibagikan.

Keadaan tersebut mengakibatkan juga kurang optimalnya kinerja karyawan dikarenakan kurangnya kerjasama antar karyawan dan pemimpin yang menimbulkan kurangnya tanggung jawab karyawan dalam bekerja. Hal seperti ini di PT AL-Barokah Natar Lampung Selatan masih terjadi sebab pemimpin di perusahaan ini sudah melakukan 
pemimpinan transaksional yang baik tetapi masih sedikit kurang optimal penyampaiannya kepada karyawannya.

Pemimpin pada PT AL-Barokah Natar Lampung Selatan sebenarnya sudah melakukan tugasnya layaknya pemimpin dalam perusahaan pada umumnya seperti menampung keluhan para karyawannya, memberikan keringanan kerja karyawan dengan melakukan terjun langsung dalam divisi yang ada, tetapi hal tersebut masih kurang optimal.

Peristiwa ini dapat digambarkan bahwa kepemimpinan transaksional sebenarnya memiliki hubungan penting dalam meningkatkan kinerja karyawan PT Al-Barokah Natar Lampung Selatan. Berikut jumlah karyawan PT Al-Barokah Natar Lampung Selatan pada tahun 2016.

Berdasarkan latar belakang diatas maka peneliti tertarik untuk melaksanakan penelitian dengan mengambil judul "Pengaruh Kepeimpinan Transaksional Terhadap Kinerja Karyawan Pada PT Al-Barokah di Natar Lampung Selatan"

\section{KAJIAN TEORI}

\section{Pengertian Manajemen}

Kata manajemen berasal dari bahasa inggris Manage yang memiliki arti mengelola/mengurus, mengendalikan, mengusahakan dan juga memimpin. Manajemen adalah sebuah proses dalam rangka untuk mencapai suatu tujuan organisasi dengan cara bekerja secara bersama sama dengan orang - orang dan sumber daya yang dimiliki organisasi (Djahair, 2014).

Menurut Mary Parker F Pengertian manajemen adalah sebagai suatu seni, tiaptiap pekerjaan bisa diselesaikan dengan orang lain (Djahair, 2014). Menurut Wilson Manajemen adalah sebagai sebuah rangkaian tindakan yang dilakukan oleh para anggota organisasi dalam upaya mencapai sasaran organisasi. Proses merupakan suatu rangkaian aktivitas yang dijalankan dengan sistematis (Djahair, 2014).

Manajemen adalah ilmu serta seni dalam menjalankan aktivitas suatu organisasi. Aktivitas tersebut bisa berupa pengorganisasian yang meliputi Perencanaan , Penyusunan , Pengusahaan dan Pengawasan dengan mengerahkan semua sumber daya yang dimiliki oleh organisasi supaya tujuannya terealisasi (Djahair, 2014).

1. Perencanaan adalah sebuah proses mendifinisikan tujuan dari organisasi, menyusun strategi untuk mencapai tujuan yang ditetapkan tersebut dan merancang aktivitas kerja organisasi tersebut (Djahair, 2014).

2. Pengorganisasian adalah proses yang meliputi bagaimana strategi yang sudah dirumuskan pada saat tahap perencanaan digambarkan pada sebuah struktur organisasi yang tangguh, sesuai, dan lingkungan yang kondusif. Pengorganisasian bisa memberikan kepastian bahwa pihak pihak yang berada dalam organisasi bisa bekerja bersama sama dengan efektif dan efisien (Djahair, 2014).

3. Pengarahan adalah tahap dimana program diimplementasikan supaya bisa dilakukan oleh seluruh pihak yang terlibat dalam sebuah organisasi. Pengarahan sebuah upaya dalam memotivasi pihak pihak tersebut agar bisa melaksanakan tanggung jawabnya dengan kesadaran penuh dan tingkat produktifitas yang sangat tinggi (Djahair, 2014).

4. Pengendalian adalah upaya untuk memastikan semua kegiatan yang dijalankan bisa berjalan dengan semestinya, sesuai dengan tahap dan target yang telah ditetapkan walaupun ada beberapa perubahan perubahan 
minor yang bisa terjadi didalam lingkungan yang dihadapi (Djahair, 2014).

Manajemen Operasional adalah suatu usaha pengelolaan secara maksimal penggunan semua faktor produksi yang ada baik itu tenaga kerja (SDM), mesin, peralatan, raw material (bahan mentah) dan faktor produksi yang lainnya dalam proses tranformasi untuk menjadi berbagai macam produk barang atau jasa (Djahair, 2014) .

Lingkup Manajemen Operasional (Djahair, 2014):

1. Perancangan desain system produksi dan operasional

a. Seleksi serta perancangan desain produk

b. Seleksi serta perancangan proses dan peraalatan

c. Pemilihan site dan lokasi perusahaan serta unit produksi

d. Rancangan tata letak serta arus kerja

e. Rancangan atas tugas pekerjaan

f. Strategi produksi dan operasional serta pemilihan kapasitas

2. Pengoperasian sistem produksi dan operasional

a. Menyusun rencana produk dan operasional

b. Perencanaan dan pengendalian atas persediaan serta pengadaan bahan

c. Pemeliharaan utilitas mesin dan juga peralatan

d. Pengendalian atas mutu

e. Manajemen sumber daya manusia (tenaga kerja)

3. Pengambilan Keputusan Dilihat dari sudut pandang kondisi atas keputusan yang harus ditempuh, ada empat (4) macam pengambilan keputusan (Djahair, 2014) :

a. Pengambilan keputusan mengenai suatu peristiwa yang pasti

b. Pengambilan keputusan mengenai peristiwa yang memiliki resiko c. Pengambilan keputusan mengenai suatu peristiwa yang tak pasti

d. Pengambilan keputusan mengenai peristiwa yang muncul akibat pertentangan dengan kondisi yang lain.

\section{METODE PENELITIAN}

\section{Objek Penelitian}

Penelitian ini dilakukan dengan mengambil lokasi di PT Al Barokah natar yang beralamatkan di jalan Al-Mubarokah No. 268 Kelurahan Merak Batin Kecamatan Natar Kabupaten Lampung Selatan. Penelitian ini dilaksanakan pada tanggal 1 februari 2017 sampai dengan 31 maret 2017.

\section{Metode dan Teknik Pengumpulan Data}

Data yang digunakan pada penelitian ini adalah :

a) Data primer adalah sumber data yang langsung memberikan data kepda pengumpul data. Sugiyono (2010) data tersebut langsung dari objek peneliti baik dari responden maupun perusahaan yang mengola data guna keperluan penelitian. Seperti dengan cara memberikan kuisioner kepada para karyawan..

b) Menurut Sugiyono (2010) sumber skunder merupakan sumber data yang diperoleh dengan cara membaca, mempelajari dan memahami media lain yang bersumber dari literatur, bukubuku, serta dokumen perusahaan.

adapun teknik yang digunakan dalam pengumpulan data adalah dengan :

1. Observasi, yaitu mengadakan survey atau pengamatan langsung ke lokasi penelitian. 
2. Interview atau wawancara, yaitu mengadakan tanya jawab langsungdengan pegawai padaKantor Dinas Pekerjaan Umum dan Perumahan Rakyat Kabupaten Lampung Barat.

3. Dokumentasi, yaitu mengumpulkan dan mencatat dokumentasi yang relevan.

4. Quisioner, yaitu membuat pertanyaan yang berhubungan dengan varibael penelitian.

\section{Sampel dan Populasi}

Menurut Arikunto (2005) apabila subyek penelitian berjumlah kurang dari 100, lebih baik diambil semua sehingga penelitiannya merupakan penelitian populasi, populasi disini ialah karyawan divisi gula pada PT.AL-Barokah Natar Lampung Selatan yang berjumlah 30 orang.

\section{Metode Analisis Data}

Analisis data menggunakan data yang telah diperoleh akan dianalisis secara kualitatif serta diuraikan dalam bentuk deskriptif. Menurut Arikunto (2005) metode analisis kualitatif merupakan penelitian bukan eksperimen, karena tidak dimaksudkan untuk mengetahui akibat dari suatu perlakuan. Penelitian deskriptif peneliti dengan maksud menggambarkan atau menerangkan gejala yang sedang terjadi.

Analisis data kuantitatif merupakan perhitungan matematis menggunakan rumus tertentu yang digunakan untuk mengetahui hasil yang diteliti. Penelitian ini menggunakan uji instrumen penelitian yaitu uji validitas dan realibilitas, serta menggunakan analisis regresi linier sederhana untuk mengetahui pengaruh kepemimpinan transaksional terhadap kinerja karyawan dengan uji hipotesis secara parsial (uji t).

Menurut Ghozali (2007) Uji t pada dasarnya menunjukkan seberapa jauh pengaruh satu variabel bebas secara individual dalam menerangkan variasi variabel dependen. Variabel dikatakan berpengaruh apabila sig $<\alpha$.

Pengujian ini dilakukan dengan tingkat keyakinan 95\% dengan ketentuan sebagai berikut:

- Jika thitung $>t_{\text {tabel }}(0,05)$, maka Ha didukung, Ho tidak didukung

- Jika $t_{\text {hitung }}<\mathrm{t}_{\text {tabel }}(0,05)$, maka Ha tidak didukung, Ho didukung DF (Degree of Freedom).

$$
D F=n-2
$$

Keterangan :

$\mathrm{N}=$ jumlah sampel

Hasil uji t dapat dilihat pada output coefficient dari hasil analisis regresi sederhana.

\section{HASIL DAN PEMBAHASAN}

Pengujian analisis data ini meliputi uji validitas, uji reabilitas, dan uji hipotesis. Perhitungan analisis data ini menggunakan perangkat lunak Program SPSS 22 For Windows.

\section{Analisis Kualitatif}

\section{Uji Validias}

Menurut Ghozali (2013) uji validitas digunakan untuk mengukur valid atau tidaknya suatu pernyataan dalam kuesioner. Teknik uji validitas yang digunakan dalam penelitian ini adalah teknik analisis faktor dengan bantuan software SPSS versi 22. Dari hasil olah data menggunakan SPSS tersebut dibuatlah tabel hasil sebagai berikut :

Tabel Hasil Uji Validitas r Tabel dan r Hitung 


\begin{tabular}{|c|c|c|c|c|}
\hline Variabel & Item & $\begin{array}{c}\mathbf{r} \\
\text { tabe } \\
1 \\
\end{array}$ & $\begin{array}{c}\mathbf{r} \\
\text { hitun } \\
\mathbf{g} \\
\end{array}$ & $\begin{array}{c}\text { Keteranga } \\
\mathbf{n}\end{array}$ \\
\hline \multirow{6}{*}{$\begin{array}{l}\text { Kepemimpin } \\
\text { an } \\
\text { transaksional } \\
\text { (X) }\end{array}$} & $\mathrm{X} 1.1$ & \multirow{16}{*}{$\begin{array}{c}0,36 \\
1\end{array}$} & 0,504 & Valid \\
\hline & $\mathrm{X} 1.2$ & & 0,639 & Valid \\
\hline & $\mathrm{X} 1.3$ & & 0,386 & Valid \\
\hline & $\mathrm{X} 1.4$ & & 0,697 & Valid \\
\hline & $\mathrm{X} 1.5$ & & 0,527 & Valid \\
\hline & $\mathrm{X} 1.6$ & & 0,396 & Valid \\
\hline \multirow[t]{10}{*}{ Kinerja (Y) } & Y1.1 & & 0,993 & Valid \\
\hline & Y1.2 & & 0,993 & Valid \\
\hline & Y1.3 & & 0,703 & Valid \\
\hline & Y1.4 & & 0,993 & Valid \\
\hline & Y1.5 & & 0,821 & Valid \\
\hline & Y1.6 & & 0,615 & Valid \\
\hline & Y1.7 & & 0,993 & Valid \\
\hline & Y1.8 & & 0,703 & Valid \\
\hline & Y1.9 & & 0,703 & Valid \\
\hline & $\begin{array}{c}\text { Y1.1 } \\
0\end{array}$ & & 0,993 & Valid \\
\hline
\end{tabular}

Sumber : Lampiran, 2017

Untuk mengetahui validitas kuisioner dilakukan dengan membandingkan $r_{\text {tabel }}$ dengan $r_{\text {hitung }}$. Ketentuan bilarhitung $>$ rtabel maka pernyataan tersebut valid.

Untuk menentukan nilai $r_{\text {tabel }}$ yaitu dengan menggunakan

$D F($ degree of fredom $)=30-2$

dengan kemaknaan $5 \%$ yaitu 0,361

(lampiran). Berdasarkan tabel tersebut dapat diketahui, bahwa semua pernyataan valid.

\section{Analisis Data Kuantitatif}

Hasil perhitungan dengan rumus analisis regresi linier sederhana menggunakan alat bantu perhitungan SPSS 22 sebagai berikut :

abel Hasil Regresi Linier Sederhana Kepemimpinan Transaksional Dan Kinerja

Coefficients

\begin{tabular}{|c|c|c|c|c|c|}
\hline \multirow[b]{3}{*}{ Model } & \multicolumn{4}{|c|}{ Coefficients $^{\mathrm{a}}$} & \\
\hline & \multicolumn{2}{|c|}{$\begin{array}{l}\text { Unstandardized } \\
\text { Coefficients }\end{array}$} & \multirow{2}{*}{$\begin{array}{l}\text { Standard } \\
\text { ized } \\
\text { Coeffici } \\
\text { ents } \\
\\
\text { Beta }\end{array}$} & \multirow[b]{2}{*}{$\mathrm{t}$} & \multirow[b]{2}{*}{ Sig. } \\
\hline & B & $\begin{array}{l}\text { Std. } \\
\text { Error }\end{array}$ & & & \\
\hline 1 (Constant & 23,178 & 5,187 & & 4,468 & ,000 \\
\hline
\end{tabular}

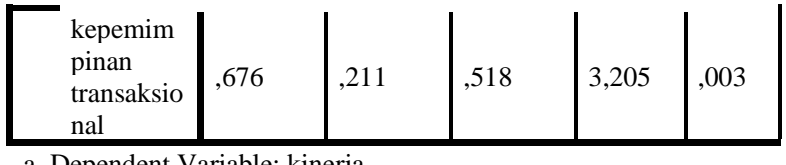

a. Dependent Variable: kinerja

Sumber : Data Diolah , 2017

$$
\begin{array}{r}
Y=\alpha+\beta 1 X+T \\
23,178+0,676 x+t
\end{array}
$$

Keterangan :

$\mathrm{Y}=$ Kinerja Karyawan

$\mathrm{X}=$ Kepemimpinan Transaksional

$\alpha=$ konstanta

$\beta 1=$ koefisien regresi

et $=$ error term

Berdasarkan hasil perhitungan tabel diatas bahwa hubungan variabel saling berfungsi satu sama lain.

\section{Uji Hipotesis}

Uji hipotesis secara uji t digunakan untuk mengetahui pengaruh secara signifikan masing-masing variabel variabel bebas terhadap variabel terikat secara parsial dengan menggunakan Uji t pada tingkat kepercayaan $95 \%$ atau dengan nilai $\alpha=5 \%$ serta dengan menggunakan kebebasan DF (Degree of Freedom).

$$
D F=n-k-1=30-1-1=28
$$

Diperoleh nilai $\mathrm{t}$ Tabel $(5 \%: 30)=$ 0,361 berikut hasil uji t dapat dilihat pada Tabel sebagai berikut

Tabel Uji t Untuk Hipotesis

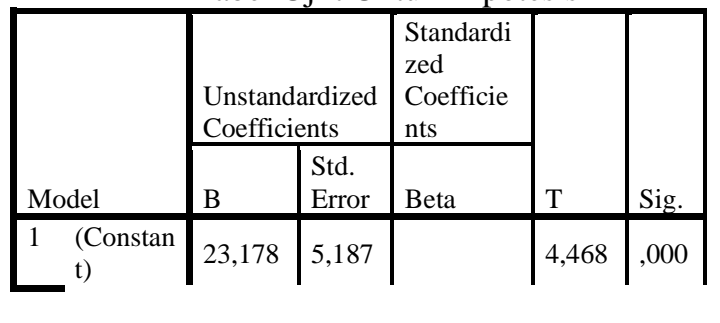


\begin{tabular}{|l|l|l|l|l|l|}
\hline $\begin{array}{l}\text { kepemi } \\
\text { mpinan } \\
\text { transaksi } \\
\text { onal }\end{array}$ &, 676 &, 211 &, 518 & 3,205 &, 003 \\
\hline
\end{tabular}

a. Dependent Variable: kinerja

Variabel kepemimpinan transaksional dengan nilai $t_{\text {hitung }} 3,205>t_{\text {tabel }} 1,701$. hal ini berarti variabel kepemimpinan transaksional memiliki pengaruh positif dan signifikan terhadap kinerja karyawan PT Al Barokah Natar, maka dapat disimpulkan bahwa Ho tidak didukung dan $\mathrm{Ha}$ didukung, yang berarti bahwa jika kepemimpinan transaksional ini mendukung hipotesis dan berpengaruh positif terhadap kinerja. Sesuai dengan teori Hasibuan (2002) kepemimpinan secara transaksional yang diberikan para atasan kepada karyawan dapat mempengaruhi kinerja karyawan di dalam suatu perusahaan. Kinerja merupakan suatu hasil kerja yang dicapai seseorang dalam melaksanakan tugas-tugas atau kecakapan, usaha dan kesempatan dapat memperoleh imbalan kerja dalam jumlah yang layak sesuai dengan hasil kerja sehingga karyawan terpacu untuk bekerja lebih baik.

\section{KESIMPULAN DAN SARAN}

\section{Kesimpulan}

Sesuai dengan tujuan penelitian
yaitu untuk mengetahui kepemimpinan transaksional berpengaruh terhadap kinerja karyawan maka simpulan yang dapat ditarik dari hasil penelitian dan pembahasan yaitu bahwa penelitian ini mendukung hipotesis yang diajukan.

Variabel kepemimpinan transaksional $(\mathrm{X})$ berpengaruh positif dan signifikan terhadap kinerja (Y) karyawan pada PT Al-barokah Natar Lampung Selatan. Pengaruh sebesar $67,60 \%$ dan sisanya dipengaruhi oleh faktor lain yang tidak ada dalam penelitian

\section{Saran}

Beberapa hal yang menjadi masukan pada penelitian ini berdasarkan hasil dan pembaasan yang telah dipaparkan adalah :

1. Saran bagi pemimpin PT Al Barokah Natar adalah hendaknya pemimpin memberikan peringatan dan sanksi apabila terjadi kesalahan pada proses kerja yang dilakukan karyawan.

2. Karyawan terlebih dahulu merencanakan apa yang akan dilakukan agar optimal dalam menjalankan pekerjaan yang ada.

3. Karyawan hendaknya tidak melakukan pekerjaan dengan tenggang waktu yang singkat agar dapat bekerja secara efisien

4. Karyawan hendaknya tidak melakukan hal yang dapat merugikan organisasi.

5. Karyawan hendaknya menjauhkan hal hal yang negatif yakni seringnya membuat salah dibanding orang lain ditempat kerja karna dapat merugikan orang lain maupun diri sendiri.

6. Karyawan hendaknya lebih meningkatkan kepercayaan diri agar tidak mudah terpengaruh pada sisi yang negatif dalam melakukan pekerjaan.

7. Karyawan hendaknya tidak membicarakan hal yang negatif diluar kantor tentang pekerjaan yang ada dalam perusahaan karna dapat merugikan organisasi itu sendiri.

\section{DAFTAR PUSTAKA}

Arikunto,2005. Manajemen Penelitian. Jakarta : Rineka Cipta

Bass, M. Bernard dan Riggio, E. Ronald. 2006. Transactional Leadership. Second Edition. New Jersey: Lawrence Erlbaum Associates, Inc. 
Byars and Rue. 2000. Human Resource Managemen : A Practical Approach. New York: Harcount Brace.

Djahair,Yulia dan Dewi, Pratita. 2014. Bahan Ajar sistem Informasi Manajemen. Yogyakarta: Deepublish.

Ghozali, Imam. 2007. Aplikasi Analisis Multivariate Dengan Program SPSS. Semarang: BP- Universitas Diponogoro.

Ghozali, Imam. 2013. Aplikasi Analisis Multivariat dengan Program SPSS. Edisi Ketujuh. Semarang: Badan Penerbit Universitas Diponegoro.

Hasibuan, Malayu S.P, 2006. Manajemen Dasar, Pengertian, dan Masalah,Edisi Revisi, Jakarta:Bumi Aksara.

Hasibuan, Malayu. 2013. Manajemen Sumber Daya Manusia. Jakarta: Bumi Aksara.

Hastono,Sutanto Priyo. 2006. Analisis Data. Universitas Indonesia.

Handoko, T. Hani. 1999. Manajemen Edisi kedua. Yogyakarta: BPFE.

Irawan, .2002. Manajemen Personalia. Yogyakarta:BPFE.

Istiyanto, 2006. Riset Sumberdaya Manusia. Jakarta: PT. Gramedia Pustaka Utama.

Luthans, Fred. 2006. Perilaku Organisasi. Yogyakarta: Andi. 